prayers and arrest. But this tradition is also evident throughout the ministry of Paul as recorded in his letters, and it is especially evident in the lives of the first disciples.

The confessional life is an obvious ingredient in almost all the great autobiographies of the Western tradition. As such, it especially constitutes the core value of the Liberal Democratic tradition. The direct and intimate integration of the confessional life into an organized social activism was the central feature of much leftwing Protestant sectarianism, and it remains so among the liberation theologians of our own day.

REVIEW FOR

FINAL EXAMINATION

\section{Selected References}

Anderson, Bernhard. 1986. Understanding the Old Testament, 4th edition. Engle- wood Cliffs: Prentice-Hall.

Boman, Thorlief. 1960. Hebrew Thought Compared to Greek. Philadelphia: Westminster Press.

Brown, Robert McAfee. 1984. Unexpected News: Reading the Bible with Third World Eyes. Philadelphia: Westminster Press.

Buttrick, George A., ed. 1952-1957. The Interpreter's Bible, Vols. 1-2. New York: Abingdon-Cokesbury Press.

Chase, Mary Ellen. 1956. Life and Language in the Old Testament. London: Collins.

Cullman, Isaac. 1956. The State in the New Testament. London: SCM Press.

Kee, Howard et al. 1983. Understanding the New Testament, 4th edition. Englewood Cliffs: Prentice-Hall.

Miranda, Jose. 1974. Marx and the Bible. Maryknoll: Orbis Books.

Pederson, J. 1926. Israel, Vols. I and II. London: Oxford University Press.

Roelofs, H. Mark. 1988. "Hebraic-Biblical Political Thinking,"' Polity, Vol. XX, No. 4, Summer, 572-97.

Roelofs, H. Mark. 1988. "Liberation Theology: The Recovery of Biblical Radicalism," The American Political Science Review, Vol. 82, No. 2, June, 549-66.

Rowley, H. H. 1956. Growth of the Old Testament. London: Hutchinson Univer- sity Library.

Snaith, Norman H. 1960. Amos, Hosea, and Micah. London: The Epwith Press.

Wallis, Jim. 1976. Agenda for a Biblical People. New York: Harper \& Row.

Walzer, Michael. 1985. Exodus and Revolution. New York: Basic Books.

Welsh, D. R., trans. 1965. Encyclopedia of the Bible. Englewood Cliffs: PrenticeHall.

Yoder, John Howard. 1972. The Politics of Jesus. Grand Rapids: Eerdsmans Publishing $\mathrm{Co}$.

\section{About the Author}

H. Mark Roelofs is professor of politics at New York University where he primarily teaches political philosophy. His most recent book is The Poverty of American Politics: A Theoretical Interpretation, soon to be published by Temple University Press.

\title{
Outcomes Assessment: One Department's Experience with Portfolios and Outside Evaluators
}

\author{
Joan Hulse Thompson, Beaver College
}

\author{
" Evaluation of students' over-all \\ performance is probably the most \\ neglected element of the major pro- \\ gram," John C. Wahlke reported for \\ the APSA Task Force on the Polit- \\ ical Science Major (1991, p. 55). \\ "Evaluation of the effectiveness of \\ the political science program itself is \\ an equally important, even more \\ rarely addressed problem,"' he con- \\ tinued (1991, p. 56). A survey of \\ outcomes assessment in political sci- \\ ence, published in the June 1991 \\ issue of $P S$, reports that "fewer than \\ one out of six responding institutions \\ had ... a policy ... mandating the \\ collection of certain types of out- \\ comes assessment data" (Julian, \\ Chamberlain and Seay, pp. 206-07). \\ External mandates for assessment, \\ however, already exist in certain \\ states and are expanding rapidly.
}

The Department of Education has adopted "a nationwide requirement that all regional accrediting agencies include assessment components as part of their accreditation provisions" (Julian et al., p. 206). Some faculty are unaware or have chosen to resist the momentum behind this national movement. As political scientists, we should seek ways to influence the development of assessment tools, to prevent the misuse of the data collected, and to use outcomes assessment to further our educational goals.

The political science department at Beaver College began the task of developing a means of documenting and assessing learning in the major during 1988. Although we have come a long way, the process is still evolving, and significant changes have been made after each graduating class. Most of the pieces are now in place, but some of them are new for the class of 1992 .

Our experience is shaped by the fact that, except for one cross-listed course and an occasional adjunct faculty member, our department consists of two people. While small departments are not uncommon, we share one tenured position, teaching additional courses each semester as overload. Most courses are offered on a two-year cycle.

Beginning with the class of 1989 , we took an existing senior thesis requirement and extended it into a small portfolio composed of the following: student learning goals prepared in the context of departmental goals; a sample of previous work in a political science course; and the 
thesis itself. All major programs at Beaver are required by the faculty to have a senior thesis project, and a portion of a Knight Foundation Grant is devoted to faculty development for supervising thesis projects.

During the last week of classes in the spring semester, seniors from various majors present their projects in a variety of public formats. Choosing to use a portfolio technique for assessment enabled us to build upon what our students were doing in their political science courses and what we, and other departments at Beaver, were already requiring of seniors. As the instructor in the senior seminar or capstone course, I have been primarily responsible for developing and overseeing the assessment project.

Each year, an outside evaluator reviews the work of political science students and suggests revisions in our capstone course. The faculty reviewers have been Gordon Henderson of Widener University in 1989 and 1990 and, last year, E. Fletcher McClellan from Elizabethtown College. This year, the political science department is conducting a program review, which includes a comprehensive selfstudy and a more extensive outside evaluation.

Our departmental learning goals were set by us three years ago and revised last year. The responsibility of the senior thesis reviewer has been to assess how well students are meeting goals and to suggest ways to boost performance. The reviewers have provided valuable feedback and enabled our department to benefit from the experience of other nearby programs.

Our assessment project, like many others, was begun in response to a directive from an authority outside the department, in our case, the academic dean. The mechanism was left to us, but validation from outside the college each year was required. It was apparent to us that the choice we made could, over time, alter the way we taught as well as what we taught. Our initial goal was to avoid a change that would be detrimental to what we consider the goals of a liberal arts education. Actually, the results have clearly been beneficial. We have raised standards, and we are providing more guidance and structure to assist students to meet those standards.

Beaver has an institutional commitment to writing across the curriculum and to fostering skills in critical thinking, oral communication, and collegial learning. As a comprehensive college, Beaver seeks to combine liberal arts and career preparation. These goals and those that underlie the structure of the political science major, as we redesigned it in 1986, formed the framework for building departmental learning goals. The initial list was one of general phrases. Last year, we began to operationalize our expectations for student learning, including the ability to use what they have learned. The senior seminar includes review of research formats and methodology, a career workshop, peer review sessions, intermediate deadlines and conferences with faculty, a group presentation analyzing a published research article and individual presentations of work-inprogress.

Instituting assessment, as it has elsewhere, got us talking more about teaching and learning. We do not team teach our courses, and we have different attitudes towards political science theory and methodology. Our teaching and testing styles are also quite different, although we both use a variety of classroom techniques, including small groups and simulations. We share our commitment to experiential learning with our students, but only those political science majors who choose the International Studies Program, as a minor, are now required to have overseas study, internships, or other off-campus experience. The Beaver College Center for Education Abroad provides special incentives to encourage participation by Beaver students in political science and other majors.

Our choice of portfolios was guided by sentiments similar to those Wahlke expressed in his task force report. He wrote that "the goal for study in a political science major is to maximize students' capacity to analyze and interpret the significance and dynamics of political events and governmental processes" (1991, p. 49). Political science graduates, his task force concluded, should be prepared to evaluate and perhaps to shape the policies and politics of the future. The goals he proposes transcend, but also encompass, the more traditional ones of preparation for responsible citizenship or for careers in law, government, or political science.

Wahlke called for evaluation procedures for student learning in political science that would emphasize "not merely the quantity of information retained, but the coherence and inter-connectedness of (that) knowledge, and (the) analytic ability (to deal) with new problems or situations"' (1991, p. 56). The results of standardized tests, he observes, could be misused in an attempt to rank programs. In fact, the doubts that have been raised about the validity of the tests in recent years make them inappropriate even "as measures of individual attainments and abilities" (1991, p. 56).

Standardized tests provide a number, but little sense of intellectual growth or what the student may achieve in the future. They do little to prompt the student to review and evaluate his/her learning and to develop the skills to assess his/her work in the future. Portfolios, in contrast, document the learning process over time, as well as providing evidence of learning outcomes. The student participates in putting them together and may discuss their meaning with others. An alternative to our approach, piloted elsewhere, brings faculty examiners from another college to conduct discussions with students about their program and, in some cases, their written work (Schneider 1989). However evaluated, portfolios encourage students to see learning as a continuous process which they can pursue effectively even after graduation.

Pat Hutchings, of the American Association for Higher Education and formerly at Alverno College, explains that,

\footnotetext{
Assessment presumes a kind of learning in which students-knowing what is expected of them-can with practice over time become their own best assessors. The object here is graduates who know their own strengths and weaknesses, can set and pursue goals, who monitor their own progress and learn from experience. (1990b, p. 7)
} 
Such students, she explains, can learn more easily and tend to better retain what they have learned. For liberal arts majors, especially those who may or may not pursue a career directly related to their major, this model of education has great value. A political science student with such an education is empowered to deal with the challenges presented by the world beyond college.

Making students responsible for their own learning must be the ultimate goal of a college education. Portfolios can be a part of a program that meets that goal. Experiential learning, such as internships and study abroad programs, should be part of it too (see Wahlke 1991, p. 55). Portfolios incorporating senior projects can encourage students to review their entire program and look for connections between their courses as well as between courses and internships or other experiences. We are encouraging students to choose topics for their senior thesis projects that make it a capstone by building on their experiences either inside or outside of the classroom.

Programs that rely upon standardized tests for assessment have had difficulty motivating students. After conversations with faculty, Hutchings and Elaine Reuben reported that, "in an attempt to get students not only to participate (to show up in the gym for a testing session), but to make their best effort, campuses have tried everything from pizzas to movie tickets to outright cash"' (1988, p. 51). This is the result of making assessment an add-on rather than a meaningful part of a student's college career.

Of course, "there are plenty of reasons not to use portfoliosthey're bulky, time-consuming, difficult to make neat sense of, maybe not what the (external mandating authority) had in mind, and they are in an early, unproven stage of development" (Hutchings 1990a, p. 8). Other means may be more appropriate for some departments, and a combination of measures, including collecting some standardized test results and surveying recent graduates, is probably essential for thorough assessment of program outcomes. Some form of capstone or integrative course as an exit require- ment is gaining acceptance, however. Tying that course to assessment makes good educational and practical sense, and portfolios are a valuable means of making that connection.

With two faculty members and fewer than ten seniors a year, we started doing portfolios and making refinements as we learned more, either from our own experience or that of others. This year we have expanded the portfolio, and each item will include the student's reflection on its content or importance. The portfolio for our 1992 graduates will include the following:

1. The student's reflection on his/ her major program, including the interconnections that they perceive and how their senior thesis topic can serve as an appropriate capstone. This essay, begun in September but revised during the fall, will enable the seniors to tie together their coursework, interests, and political experiences. It will serve to introduce their learning goals for their thesis, outline their career goals, and conclude with their resume. This first piece will enable the outside evaluator to know the students better and give the students an initial chance to practice self-assessment.

2. A previous paper from a political science course at Beaver and a brief description of how they might have written it differently or might revise it.

3. The abstract and analysis of a published article, which they produce with one or more partners for the senior seminar. The individual student will add a comment on the collaborative experience and on how and why this project did or did not help them with their thesis.

4. The senior thesis, 25 to 30 pages, with approximately 20 sources, two of which must be personal interviews (unless exempted). A final statement from the student will describe what they were pleased and/ or displeased with about their thesis. An abstract of the thesis, written for a campus audience, is prepared for the public presentation and will also be included. If students are dissatisfied with their project in some way, the abstract can reflect more closely how they wished they had approached the topic than the actual content of the paper.
The public presentation has been a valuable opportunity for those students who perform better orally than in writing. Senior Art Thesis at Beaver has been a tradition for 20 years, and public presentations from other programs have become established quickly. Ours attracts a diverse audience, some of whom come for only a part of the program. They include roommates, friends, family members, other faculty, student affairs staff, administrators and, of course, political science students.

The seniors talk about how their project complements their major program, their most significant sources including personal experience and interviews, and their paper thesis and conclusions. At the end of each panel, we plan time for questions or comments from department faculty and the audience. This past year two students commented on the connections between their individual projects. Next year we will cut our program back from two hours to 90 minutes, if possible.

Our original idea for the panel was to have a political science conference format with the outside evaluator serving as a panel discussant. We found that public criticism, however mild and well deserved, was very upsetting to some undergraduates. Furthermore, it really did not serve our purposes very well.

The format we tried this year spotlights the students and gives them the opportunity to demonstrate the expertise they have achieved on a specific topic. It emphasizes achievement and competencies rather than deficiencies. We invite the students to set up displays of their source material for the informal social time between the domestic and foreign policy panels. We have food, a program with the students' names and topics and, beginning in 1992, junior majors will distribute programs and abstracts at the door. This spring, we may videotape the panels and displays so that the outside evaluator will be able to view them, even if he or she is unable to attend. That would then become the final piece of the portfolio.

Another goal for this spring is to begin to provide our outside evaluator with a better sense of what we expect from him/her. One of the 
major drawbacks of portfolios is that evaluation criteria must be generated by the department in line with the goals it has set for student learning. Over the summer, I developed a checklist for evaluation of the senior thesis that borrows heavily from materials used by Beaver faculty in other departments. For portfolios, we need questions that deal with the connections between courses, experience, and the thesis as perceived by the student and that allow the evaluator to comment on the student's development in terms of specific skills and his/her ability to engage in self-assessment.

This year, we will use the senior thesis evaluation forms, adding an open-ended question directed to the portfolios as a whole. Copies of evaluation forms will be sent to students, and the evaluator will continue to write a letter providing overall feedback to the department. The letter and the forms for each senior will become part of the assessment materials for the department. This year, in connection with our department review, we hope to finalize the assessment program. We will reexamine the portfolio format, revise the evaluation criteria, if necessary, and, if possible, determine what other information we need to collect for a complete picture of student learning in the major.

Another project for the future is the handbook for political science majors that was suggested by the Wahlke task force (1991, p. 57). It would enable us to build identification with the program, further promote experiential learning and encourage students to start thinking sooner about goals and outcomes for themselves. We use the APSA career booklet for undergraduate political science majors now, but not until senior seminar.

For faculty, getting involved in assessment is time consuming and it means holding ourselves accountable. "Accountability here means delivering an education equal to that promised in recruitment, to the student's investment (not only of money but of time and effort), and to the demands of the student's postcollegiate life" (Hutchings 1990b, p. 8). If we as political scientists do not get more involved, however, we will forfeit the opportunities that exist now for influencing the process. For in political science as in other disciplines, 'what's most at stake here are educational values. Choosing portfolios is choosing to enact-and communicate to students-a view of learning as involving, personal, connected, and ongoing"' (Hutchings 1990a, p. 8).

\title{
A Report on the Advanced Placement Program in Political Science
}

\author{
Frank L. Wilson, Purdue University
}

This year marked the fifth year of the College Board's Advanced Placement Program in Government and Politics. This program offers high school students the opportunity to earn college level credit for two standard political science courses: "Introduction to U.S. Government and Politics" and "Introduction to Comparative Politics." The courses are offered in the high schools by teach- ers who follow college curricula and use college level textbooks. At the end of the school year, students who wish to establish college credit take a nation-wide examination, which includes both multiple-choice and free-response questions. The essay portion of the exam is graded by college and high school instructors.

While only five years old, the Government and Politics Program has

\section{References}

Hutchings, P. 1989. "Linking Assessment and Teaching." Assessment Update 1: 8-11.

1990a. "Learning Over Time: Portfolio Assessment." American Association for Higher Education Bulletin April: 5-8. $1990 \mathrm{~b}$. "Assessment and the Way We Work." Fifth AAHE Conference on Assessment Closing Plenary Address June: 1-8.

Hutchings, P. and E. Reuben. 1988. "Faculty Voices on Assessment." Change JulyAugust: 48-55.

Julian, F., D. Chamberlain, and R. Seay. 1991. "A National Status Report on Outcomes Assessment by Departments of Political Science." PS: Political Science \& Politics June: 205-08.

Schneider, C. 1989. "Using External Examiners to Assess Student Learning in Arts and Sciences Majors." Association of American Colleges Project Report August: 1-16. (produced for discussion purposes only, not quoted)

Wahlke, J. 1991. "Liberal Learning and the Political Science Major: A Report to the Profession." PS: Political Science \& Politics March: 48-60.

\section{About the Author}

Joan Hulse Thompson, assistant professor at Beaver College, co-chairs the political science department with her husband, Robert R. Thompson. Her major research interest has been the Congressional Caucus for Women's Issues, and she served as an APSA Congressional Fellow, 1985-86. already established itself as an important part of political science. The program has proved to be one of the most popular and most rapidly growing subjects in the Advanced Placement curriculum. The first year, 1987 , over 8,000 took the examination. In 1991, roughly 21,000 took the Advanced Placement exams in Government and Politics, and many thousands others took the course 